\title{
THE ROLE OF COMMUNICATION MANAGEMENT IN SPORTS WITH SPECIAL EMPHASIS ON HANDBALL
}

\author{
Jadranka Denkova ${ }^{1}$, Mirjeta Bajramovska ${ }^{2}$ \\ ${ }^{1,2}$ University Goce Delchev Shtip, Faculty of Law \\ Jadranka.denkova@ugd.edu.mk, bajramoskam@yahoo.com
}

\author{
Original Scientific Paper \\ doi:10.5937/jouproman6-19001
}

\begin{abstract}
Communication management plays a significant role in all aspects of social life and is increasingly representing an inevitable segment for the successful functioning of organizations. Hence, the topic of this research in order to perceive how is communication management perceived in the world of sport in the Republic of Macedonia. The main emphasis is on researching the leadership for communication in handball in the Republic of Macedonia. The significance of this work is especially pointed out in terms of the fact that sport is the basis for the development of young people in a country, both physically and mentally, and should be an indication of the creation of healthy individuals. Therefore, the internal and external communication in sports clubs will affect their achievements, the development of their image and the achievement of efficiency of sports organizations. Sport is a sensitive topic from the aspect of being directly related to the citizens as users of their services. Whether these clubs will be successful depend on how they function, what is their approach, the quality, how they communicate with the public, inside the clubs and how they communicate on a wider level, sports clubs among themselves. Bearing in mind that this work is concentrated on a serious methodological approach which analyses relevant documents, statistical indicators, as well as qualitative analysis of an interview, it can be concluded that very little attention is paid to communication management. Its significance and role is not properly understood and all this has further reflections and the negative results in sports in the Republic of Macedonia. In addition, there is a need for legal changes, training of the involved people in the field that will enable more serious approach to this scientific discipline, which would improve the efficiency of sports organizations in the Republic of Macedonia.
\end{abstract}

Keywords: communication, sports, handball, management, organizational structure.

\section{INTRODUCTION}

The approach to effective implementation of communication management using all available resources and tools applies to all types of activities and organizations, as well as the organization of sports and sports recreation. Within the communication, the management team usually uses the media tools in order to transmit the specific message. In order to implement effective communication management, there should be a clear and consistent communication plan that will determine the organizational responsibility and the types of communication that will be used in it.

However, the key role for the achievement of success in organizations is certainly, management, or management teams of different profiles, because they need to know how to effectively manage their team, as well as they need to know the overall structure of the organization.

Accordingly, the sport also becomes a productive activity where professional segment relies on the laws and conditions of the closest environment, that is, the market. Because of this, certain internal structures arise, whose effective organization is due precisely to the quality management of the selected management team of the sports club itself. 
Communication management framework in sports organizations, involves realization and implementation of processes necessary for ensuring the timely and complete creation, collection, segmentation, preparation, distribution, finding and utilization of the ultimate organizational information and available resources. When talking about communication in handball, it should be emphasized above all that communication itself is a kind of interdisciplinary field related to all branches of industry, sports, business, etc. as well as to everyday life of each person on the Earth. All the work and sports activities are based on communication between shareholders who participate in the process of connecting, i.e. communicating. Without a successful handball communication, the team as a separate group of people would not be able to reach their goals and succeed in their intentions. In a word, communication is the most important and crucial part of a successful team. In addition, communication in handball is crucial in order to achieve a successful relationship with the spectators and the audience. The aim of sport is to connect people of different nationalities, age, religions through successful intercommunication.

\section{METHODOLOGY OF THE PAPER}

The main goal of this paper is to understand the role of communication management and its carriers in the field of sports recreation, more precisely handball and handball clubs in the Republic of Macedonia. The subject of this paper is aimed at perceiving the application of communication management in handball sports clubs, how much it is applied, whether there is an application and understanding of it, and how well these issues are regulated. For the theoretical part of this paper, standard methods of secondary research are used, for which, information on the process of implementation and determining the effectiveness of communication management in handball sports clubs in the Republic of Macedonia was collected through secondary data sources, as well as their connection to the effective functioning of the sports organization. The primary source of information is a structured interview made of 12 questions, more than 10 respondents who are in charge of sports clubs. The results of the paper are based on qualitative analysis of the interview and other relevant databases, scientific and professional domestic and foreign literature, as well as various documents and information relevant to the subject of the research.

Consequently, in order to prove the hypotheses of this paper, several different methods were used to meet the basic methodological needs - objectivity, reliability, basis and systematicity of it.

During collecting, segmentation and analysis of the data, the following methods and techniques were used: data analyses, the content of the information analyses, the data relevance, checking, both primary and secondary contents and information from the already conducted research.

\section{ANALYSIS OF THE RESULTS OF RESEARCH}

If we were to analyze the handball and the sport in general over the years, we will come to the conclusion that there were positive changes, and the handball today differs from that in the past. The same can be said about the communication in the handball as well as the communication itself which is much more developed than in the years of the last century and much earlier in history. This expansion of the development of communication in the handball is directly related to the prevalence and influence of the sports industry on it. 
An undeniable fact is that sport is increasingly taking up space in the society, among people, as well as in their diverse cultures and traditions, considering the fact that a lot of people in their daily life are more committed to sport in general, some as passive active observers, some as direct participants on the field, on the playground. In the Republic of Macedonia, there are several handball clubs that are present across several cities. Such as Men's Handball Clubs: Rabotnicki, Vardar in Skopje, as well as RC Gjorche Petrov, Handball Club Delcevo, Handball Club Metalurg and Rabotnicki, as well as Handball Clubs Strumica, Kavadarci and Ovche Pole.

On the other hand, Vardar and Metalurg are part of the Women's Handball Clubs in Macedonia. It is interesting that women's handball players have only two handball clubs that have achieved much greater success in their activities in the field of sports, unlike male players with far more handball clubs in several cities in Macedonia.

However, with the greater commercialization of the success of the women's handball athletes, since 2008, there was significantly increased interest in the female public about the handball, which was followed by the creation of several junior, independent and amateur handball clubs in most cities in Macedonia. So there are other women's handball clubs such as Vardar SCBT, Vardar Junior Women, Kumanovo, Ovche Pole, Pelister, Prilep and Gjorche.

On the other hand, in the field of the men's handball clubs, the newer ones like Pelister, Prolet 62, Prilep, Ohrid 2013, Radovish, GRK Borec, Zomimak-M and Metalurg 2 stand out. Handball juniors like Vardar Junior and other smaller and amateur clubs are included in these clubs across several cities.
Sports clubs are autonomous organizational forms in relation to the sports and social environment, due to the independent component in the selection of resources and the setting of goals, as well as the ways of their realization ${ }^{1}$.

The development of management in the economy is also imposed in other areas of social life of people. Managers of the sports organizations existed long before the concepts of sports manager were created. Many sports organizations have a centuries-old tradition, as today and in the past these organizations were managed by a group or an individual.

Management can refer to profit and non-profit organizations and its applicability is different in those areas. Sport as a whole belongs to non-profit organizations and hence we can talk about the specific application of the principles of management. But today, the high level sport is more organized in the system of the profit organizations, which, like other business organizations, inevitably appear on the market. Having in mind that for the sports organization, the most important goal is to produce top results out of the human resources (athletes), the management in the sport makes functional content, the basic one. This means that without a sports organization, the management can not realize its functional content; and vice versa, the sports organization has no connecting and stimulating power of action and development without the management. In the sports organization, the management provides integrity in all processes and resources that are relevant to governance, and primarily translating ideas into successful implementation of goals.

\footnotetext{
${ }^{1}$ Havelka, N. i Lazarević, Lj. (2011). Psihologija menadžmenta u sportu. Beograd: Visoka sportska i zdravstvena škola
} 
It ensures the functioning of the entire system of the sports organization, i.e. the establishment of a system of talent selection, provides expert work and creates general conditions for preparation of the athletes for the highest achievements, creates preconditions for organizing sports competitions, provides materials and functional means, and finally provides communication with the sports public.

As in all organizations, the sports managers communicate with the employees (who are not managers) or with managers from lower levels of management. Here, it is important to note that informal communication in sports achieves greater efficiency. The sports organization, by its very nature and essence, strives to not constitute a strict hierarchical organization, and pursues more towards the establishing of quality interpersonal relations. It creates friendship and community in which informal communication plays an important role ${ }^{2}$.

Sending it to the recipient of the message, the subject who receives the given information and from which a certain response is expected. The sender has a portion of the responsibility for whether the recipient can understand the information in an appropriate and expected manner.

In addition to the analysis of the relevant document and theories related to communication management, this part also includes analysis of the results obtained through interviews of more than 10 participants (relevant people from sports clubs in the Republic of Macedonia).

\footnotetext{
2 Temelkovski, S. (2009). Sportski menadzment. Skopje: Agencija za mladi i sport i Sojuz na sportski federacii na Republika Makedonija.
}

They were asked 12 previously structured questions related to communication management and were asked how they perceive them, if they implement them and also other questions needed to obtain an overview and information about the attitude towards communication management in handball.

The interview was carried out with managers, secretaries and other relevant responsible people from the following sports clubs: the Academy of Handball Club Metalurg, Handball Club (HC) Zeleznicar, The Union of Sports in Macedonia, HC Vardar, HC Eurofarm, HC Pelister, HC Prilep, HC Prolet, HC Spartak Kisela voda and HC CEMS. Unfortunately, several clubs and the Agency of Youth and Sports were not willing to cooperate and therefore I could not receive answers to my questions.

From the answers we received from the interview with the relevant persons in handball, and upon the conducted qualitative analysis of the interview, we can conclude that effective communication management is one of the main tools for achieving the success of the handball clubs in the Republic of Macedonia; and a small part of the interviewed responsible persons in the handball clubs understand its significance. From the results of the research we came to the conclusion that the handball clubs in the Republic of Macedonia need some improvement and upgrading of the models of effective communication management, especially in the framework of the realization and implementation of certain sports projects and events in the country and abroad. This means that the communication management and the success of the handball club strongly depend one on another, in the same manner as the success of the handball club is closely related to the projects and events attended by the club in the country and abroad. 
The handball clubs in Macedonia need to improve and upscale the communication management models having known that communication and management are living things that develop simultaneously with the development of the society, therefore, handball clubs should constantly keep up with the world of communication trends and communication management. Also, the research suggests that there is a need for improvement and modernization of the handball sports clubs, i.e. they should be provided with quality equipment, information, including efficient distribution of such information to the users of the services. Special emphasis should be placed on the role of the modern technology in the efficient communication management, and at the same time, the success of handball clubs in the Republic of Macedonia.

Nevertheless, it has to be accentuated that there is need to introduce organizational units for communication management as part of the handball clubs. These units shall intensively deal with implementing and carrying out communication management practices. I also believe that trainings for communication managers should be organized. Moreover, participants from handball clubs should attend those trainings and implement knowledge and recommendations from those trainings. As the chief recommendation I point out the need to implement legal acts with which handball clubs in Macedonia will have to see the importance of communication management, i.e. implementing the term communication management in the Law of sport in the Republic of Macedonia, its definition and its processing.

Communication is a prudent process in managing organizations all over the world. It is a complex process in which one has to work thoroughly and with much devotion in order to attain a successful communication process. Bearing this in mind, communication is always regarded as something that has to be enhanced in order to obtain success in functioning of one organization and its projects, implementing and anticipating, determining targets, needs, resources, condition statements as well as successful managing of the whole team and the projects included in the activities of the sports organization in this case.

If the Republic of Macedonia changes its approach in organizing and managing sport through implementing compulsory obligation for establishing rules and procedures for communication management, appoints communication management experts as well as modern technical equipment for the support of the communication management, this will create the possibility to establish efficacy in both individual and group sports.

In order to establish an effective communication system in handball, it is vital to create all compatible information activities in Macedonia that have to be constructed, compatible and on a quality level, while emphasizing the necessity for possessing modern information technology, programs and personnel that will manage them. In light of this discussion, in order to implement an effective communication information system in handball, it is necessary to organize the organizational fulfillment of the normative conditions and assumptions in order to enable the collection, processing, interpretation and distribution of information and data that are prudent for the development of handball in Macedonia . 


\section{CONCLUSION AND RECOMMENDATIONS}

The results of the paper point to the need for successful and effective communication management that will contribute to successful realization of the set up goals in handball. All of this will be accomplished through successful communication management in each sports club individually, as well as through mutual communication between all sports clubs. In this context, we can draw a conclusion that the handball clubs in the Republic of Macedonia need some improvement and upstaging of effective communication management models, especially as a part of the realization and implementation of sports projects and events in the country and abroad. With the help of the effective communication management, the handball sports clubs in the country can use, and learn how to use, all available information and resources that can contribute to successful implementation of certain short-term and long-term sports projects.

The communication management plays a great role in the sports organization and sports recreation within the handball clubs in Macedonia, especially in support of the implementation and realization of a certain sports events and projects, at the same time contributing to the successful operation and mutual communication of the organizational sports clubs and their external and internal surrounding.

However, we must emphasize the need for introduction of organizational units for communication management within the handball clubs that will intensively deal with implementation and realization of the communication management. It is also necessary to organize trainings for communication managers that should be attended by the representatives of handball clubs who will be tasked with implementation of the acquired knowledge and recommendations. The most important recommendation is to make legislative amendments and to establish legal norms that will emphasize the necessity for sports clubs to appoint responsible persons for communication, to establish procedures for internal and external communication, to develop communication plans and programs, as well as to establish models for effective communication.

\section{Bibliography}

Havelka, N. i Lazarević, Lj. (2011). Psihologija menadžmenta u sportu. Beograd: Visoka sportska i zdravstvena škola.

Temelkovski, S. (2009). Sportski menadzment. Skopje: Agencija za mladi i sport i Sojuz na sportski federacii na Republika Makedonija.

Tomić, M. (2007). Sportski menadžment.Beograd: Data status.

Dzatoska - Zdravkovska, S. (2011). Komunikaciski menadžment vo javnata administracija. Skopje: Univerzitet za turizam i menadžment.

Kokovič, D. (2000). Socijalna antropologija. Sportska akademija. Beograd.

Kokovič, D. (2001). Socijalno - psihološki osnovi sporta. Beograd: Viša košarkaška škola.

Rot, N. (1983). Psihologija grupa. Zavod za udžbenike i nastavna sredstva, Beograd.

Chadwick, S. (2009). From outside lane to insade track: sport management research in the twentyfirst century. Management Decision, 47 (1), 191 203.

Taylor, T., Dorothey, A., and Mcgraw, P. (2008). Managing people in sport organization. Burlington: Elsevier Ltd.

Onağ, Z. and Tepeci, M. Team Effectiveness in Sport Teams: The Effects of Team Cohesion, Intra Team Communication and Team Norms on Team Member Satisfaction and Intent to Remain. Procedia - Social and Behavioral Sciences 150 ( 2014 ) $420-428$.

Janićijević N., Upravljanje organizacionim promenama, Ekonomski fakultet, Beograd 2004.

Dugalić, S. Finansijski i marketinški aspekti strategija u sportu. Beograd: Visoka škola za sport (2005). 